УДК 7.03

Г.Л. Тульчинский

Санкт-Петербург

\title{
ТВОРЧЕСКОЕ НАСЛЕДИЕ ДЗИГИ ВЕРТОВА КАК УРОК ОТВЕТСТВЕННОСТИ В ИСКУССТВЕ
}

Цитирование: Тульчинский Г.Л. Творческое наследие Дзиги Вертова как урок ответственности в искусстве // Наследие. 2020, № 2(17). - С.32-45.

DOI: https://doi.org/10.31119/hrtg.2020.2.2

Citation: Tulchinskii G.L. Tvorcheskoe nasledie Dzigi Vertova kak urok otvetstvennosti $v$ iskusstve [Dziga Vertov's creative heritage as a responsibility lesson in art] // Nasledie [Heritage]. 2020, No. 2 (17). - pp.32-45.

DOI: https://doi.org/10.31119/hrtg.2020.2.2

Статья содержит попытку осмысления динамики признания творчества Дзиги Вертова от феерического успеха к практическому забвению. В 1920-х г2. новаторство кинорежиссера в основном совпадало с идеологической программой переустройства общественной жизни. В 1930-х г2. и далее интерес Вертова к выражению киноязыком эмочиональной жизни простого человека наталкивался на неприятие и отторжение. Это стало главной причиной фактического изгнания выдающегося кинорежиссера из профессии.

Ключевые слова: Дзига Вертов, кино, кинопись, ответственность, парресия.

Tulchinsky G.L. Dziga Vertov's creative heritage as a responsibility lesson in art The article contains an attempt to understand the reasons for the dynamics of recognition of Dziga Vertov's creativity from enchanting success to practical oblivion. In the 1920s the filmmaker's innovation fully coincided with the ideological program of rebuilding public life. In the 1930s and beyond Vertov's interest in expressing the emotional life of an ordinary person in cinematic language became rejected. This was the main reason for the actual expulsion of the outstanding filmmaker from the profession.

Key words: cinema, Dziga Vertov, film writing, parrhesia, responsibility.

В нынешнее время постправды, фейков, переполняющих медиа, творчество Дзиги Вертова (Дениса Аркадьевича Вертова, 1896-1954) - гениального создателя поэтической кинодокументалистики, автора «Киноправды»- вызывает особый интерес. Обусловлен этот интерес не только стилистикой, образной системой Вертова, но и судьбой восприятия его творчества, что помогает в немалой степени понять смысл концепта правды, способности говорить правду, отвечать за ее восприятие в обществе.

\footnotetext{
* Исследование выполнено при поддержке гранта РНФ № 20-68-46013 «Философско-антропологический анализ советского бытия. Предпосылки, динамика, влияние на современность».
} 
Тема оценки и признания творчества Вертова весьма многогранна, но, в принципе, может рассматриваться в нескольких основных измерениях, ракурсах. Вопервых, в плане биографическом - и это очень содержательный ракурс, в чем-то даже весьма поучительный для раскрытия и осмысления вечной темы отношения творчества, автора и общества. Профессиональный (и в целом - жизненный) путь Дзиги Вертова начинался с успехов и даже наград, сменившихся в конце 1930-х нарастающим неприятием. В результате художник прошел путь от создания шедевров документального кино, ставших классикой мирового масштаба, до забвения: неприятия и отклонения новых проектов и рутинной работы монтажера над выпусками «Хроники дня».

Случайной такая траектория быть не может. И определяющим ее фактором вряд ли может быть непростой характер самого Дзиги Вертова. Более того, сама эта конфликтность определялась, скорее всего, стилистическими нестыковками творчества автора и времени. Общество, в строительстве и презентации которого активно участвовал гений документалистики, изменилось, изменились представления и запросы правящего политического класса о форме и содержании «социального заказа». Подстройку под эти изменения также прошли режиссеры художественного, игрового кино, но для документального кино, наверное, это было более болезненно.

Во-вторых, тема отношений Вертова и общества может раскрываться в стилистическом плане. Но тут нас поджидает на первый взгляд противоречие, даже парадокс, никак не вносящий ясность в план биографический. Дело в том, что Вертов практически никогда не вступал в конфликт с советской идеологией. Наоборот, он ее поддерживал и выражал в развиваемом им «поэтическом документальном кинематографе» всей мощью своего таланта. Другими словами, его творческие установки вполне вписывались в канву утвердившегося «социалистического реализма» с его описанием реальности в контексте социально-политических идеалов будущего. Путь от «Годовщины революции» (1919), «Боя под Царицыным» (1920), «Процесса эсеров (1922), «Вчера, сегодня, завтра» (1923), «Киноправды» (1922-1925) через «Киноглаз» (1924), «Человека с киноаппаратом» (1929), «Симфонию Донбасса» («Энтузиазм») (1930) и параллельно «Шагай, Совет!» и «Шестую часть света» (1926) к «Трем песням о Ленине» (1934) и «Серго Орджоникидзе» (1937) - суть ясный и очевидный путь от радости преобразования, строительства нового мира к воспеванию силы, руководящей этими преобразованиями.

Как представляется, ответ, разрешение этой парадоксальности сто́ит искать глубже. Такой более глубокий план стилистического расхождения Вертова с официозом - и это в-третьих - лежит в отношении художника к материалу.

Наконец, в-четвертых, обобщая рассмотрение, для понимания непростой, если не трагической, судьбы Вертова, как представляется, важным является обращение к полузабытому концепту парресии как свободного и ответственного высказывания. Концепт парресии - ответственной публичной речи (устной и письменной) был в свое время подробно рассмотрен М. Фуко, отказавшим ему в существовании в современных условиях массовых коммуникаций, превращающих коммуникацию в безответственное говорение «обо всем», обилие сознательных и бессознательных фейков, фактически - безответственное публичное самовыражение [Фуко, 2010]. Однако с развитием современных медиа все более очевидным становится запрос на 
осмысление феномена «взятия слова» и готовности принять реакцию (нередко - негативную) на высказанное. И в этом плане «кейс Вертова» (фактически реального парресора) оказывается весьма показательным.

С самого начала и на всем протяжении своего творчества Вертов резко противопоставлял свой подход к кино (новаторский, революционный) подходу мещанскому, буржуазному, коммерческому. В манифесте киночества «Мы» (задуманном в 1919 и опубликованном в 1922 г.) он утверждает «будущее киноискусства отрицанием его настоящего», объявляя «старые картины, романсистские, театрализованные» и пр. - прокаженными, призывая не «трогать их глазами», «не подходить к ним близко», в силу их «заразительности» и даже «опасности для жизни» [Вертов, 2008, c.15]. От кино, «отравленного психологическим романом» с примазавшимися к нему «от музыки, от литературы и театра» - в чистое поле «жизни врасплох» с четырьмя измерениями, таящее немыслимое богатство материала и возможностей выразительных средств. И сам Вертов, и его сподвижники активно открывали и воплощали в своих замыслах эти возможности.

Главное препятствие на этом пути виделось Вертову в человеке: «У нас нет оснований в искусстве движения уделять главное внимание сегодняшнему человеку», потому что «психологическое мешает человеку быть точным..., препятствует его стремлению породниться с машиной» [Вертов, 2008, с.16]. Пафос манифеста - «исключить временно человека как объект киносъемки», «воспитать новых людей», «породнив их с машинами», «влюбляя рабочего в станок,... крестьянина в трактор, машиниста в паровоз», «через поэзию машины к совершенному электрическому человеку». В центре внимания - точные движения машин, осознание машинного ритма, красота химических процессов, кинопоэмы пламени и электростанций, радость пляшущих пил на лесопилке, а не радости человечьих «танцулек». Для Вертова в 1920-е гг. документальное кино как киночество есть «искусство организации необходимых движений вещей в пространстве и, применив ритмическое художественное целое, согласное со свойствами материала и внутренним ритмом каждой вещи» [Вертов, 2008, с.16]. Это «поэзия двигающей и двигающейся машины, поэзия рычагов и стальных крыльев, железный крик движений, ослепительные гримасы раскаленных струй» [Вертов, 2008, с.18].

«Основное и самое главное» для Вертова - «киноощущение мира» [Вертов, 2008, c.38], которое дает использование киноаппарата - «киноглаза», - более совершенного, чем глаз человеческий в фиксации и осмыслении бесконечно разнообразных зрительных явлений. «Киноглаз», по Вертову, высвобождает из жалкого рабства и подчинения несовершенному, недалекому человеческому глазу, помогая видеть мир глазами художника, и тем самым дает новые выразительные средства. Такими средствами выступают крупный и дальний план, ускоренная и замедленная съемка, управление киноаппаратом на расстоянии, микро- и рентгеносъемка, обратная прокрутка и т.д. Позже «киноглаз» квалифицировали как нечеловеческий глаз, расположенный в машине [Делез, 2004, с.135-136], как глаз человека-машины [Темлякова, 2016, с. 112].

Торжество на экране выражения чистого движения достигается не только самим отснятым материалом, но и его ритмическим монтажом. Киноглаз в понимании Вер- 
това - это и видение через киноаппарат, и описание видимого на пленке, и его осмысление в монтаже (монтажное «вижу» и «слышу»). По сути, главным оказывается именно монтаж, конструирование изображения и звукового ряда: монтаж во время наблюдения (как ориентировка не вооруженного кинокамерой глаза), монтаж после наблюдения (как мысленная организация увиденного), монтаж во время съемки (как ориентировка вооруженного глаза к обстоятельствам съемки), монтаж после съемки (предварительная организация, выявление недостающего материала), глазомер (как отбор монтажных кусков), окончательный монтаж (как выявление основной темы, смыслового стержня киновещи) [Дзига Вертов..., 1966 с.97, 114]. Киновещь для Вертова - это монтажное «вижу».

Именно монтаж выстраивает для глаз зрителей траекторию маршрута к пониманию содержания. И в этом выстраивании режиссер, освобожденный от временны́х и пространственных рамок, полновластно распоряжается имеющимся материалом, сопоставляя любые точки вселенной, где бы они ни были зафиксированы. В «Киноправде» №13 в память о погибших народных героях монтируются кадры 1918 г. в Астрахани (опускание в могилу гробов), 1921 г. в Кронштадте (засыпание могил), 1921 года в Петрограде (пушечный салют), 1922 г. в Москве (снимание шапок). В «Энтузиазме» монтируются храмы и верующие, снятые в разных местах и в разное время года.

Виртуозное владение всем этим инструментарием позволило Вертову резко раздвинуть представления о практическом его применении. Так, им была предложена целая программа развития жанров кинорекламы, включая рекламу-хронику, рекламу-трюк, рекламу-шарж, рекламу-экспромт, комическую и сатирическую рекламу, рекламу-детектив и т.д. Но главное - это мастерство, с которым эта новая стилистика воплощалась в вертовских шедеврах, ставших классикой поэтической кинодокументалистики, - не только в выпусках «Киноглаза», но и в развернутых полотнах вроде «Человека с киноаппаратом» или «Энтузиазма (Симфонии Донбасса)» - первого советского звукового фильма и первого в мировом кино, когда все содержание изобразительного и звукового рядов фиксировалось не в павильоне, а в натуре, с помощью подвижной камеры и микрофона.

Эти вертовские призывы, филиппики чрезвычайно актуальны, они написаны как будто сегодня - в условиях тотальной цифровизации, торжества расширяющих человеческие возможности технологий искусственного интеллекта, Интернета вещей, виртуального пространства, фиксации всего и вся, тотального наблюдения, контроля, то ли все больше выводя человека «за скобки», то ли интегрируя его в постчеловеческую цивилизацию.

В этом подходе изначально было заложено противоречие. Это были - одновременно - демонстративный отказ от всего «человеческого, слишком человеческого» во имя машин, механизмов и не менее демонстративная свобода самовыражение автора, не просто отображение реальной жизни, но и выражение отношения к ней автора. Причем сам Вертов это прекрасно понимал, возводя свой начальный интерес к кинодокументалистике к острому личному переживанию весной 1918 г. при возвращении с вокзала, связанному с острым сожалением о возможной утрате пережитых впечатлений от звуков и образов, убегающих, как убегает время, необходимости их записывать, организовывать и возвращать [Дзига Вертов..., 1966, с.73-74]. 
Человеку, как существу конечному в пространстве и времени, не дана вся полнота разнообразного мира, который он постигает всегда с какой-то позиции, в каком-то ракурсе, с какой-то точки зрения. В каком-то смысле «Киноглаз» расширяет возможности ракурсов, из совмещения, но все равно это остается фиксацией и выражением некоей позиции человека с киноаппаратом, монтирующего потом из отснятого киновидеоматериала некий кинонарратив, выражающий его (автора) отношение и оценку.

Показательно, что эти отношения и оценки у Вертова акцентированно идеологические. Деятельность «киноков» понимается им как «активнейшее участие в мировом переустройстве»: выступая не только барометром общего состояния масс, но и регулятором массового слуха и зрения освобожденного человечества, опираясь политически на коммунистическую программу, внедрить в кино идеи ленинизма и вложить их в труд и мысли рабочего класса. «Увидеть и показать мир во имя мировой пролетарской революции - вот простейшая формула киноков» [Вертов, 2008, c.57]. 43 выпуска «Кинонедели», 23 выпуска «Киноправды» посвящены не только советским выставкам и стройкам, но и ключевым политическим реалиям - от боев в Гражданскую войну до московских процессов эсеров и Промпартии. 13-я «Киноправда» выпущена ко дню рождения Ленина, «Вскрытие мощей Сергия Радонежского» снято по заказу Наркомпроса, «Шагай, Совет» - по заказу Моссовета, «Шестая часть мира» - по заказу Госторга для демонстрации разнообразия экспортных возможностей СССР. «Энтузиазм», снятый к Октябрьским торжествам 1930 г., начинается с покрассовского «Марша Буденного» и заканчивается маршем военных. А между ними фильм разворачивается от разгрома церквей через лепку бюста Ленина к гимнам коллективного труда, отдыха, прямо переходящим в военный марш.

Более того, пафосные нападки Вертова на игровое коммерческое кино - «пошлую слащавую и слезливую психологическую мелодраму», динамичный, но фальшивый детектив - с его театральностью и литературностью совпадали (иногда - буквально) с партийной критикой поднявшегося и разросшегося за годы НЭПа «важнейшего из искусств», фактически превратившегося «в проповедника буржуазного влияния или разложения трудящихся масс», как отмечалось в резолюции XII съезда РКП(б) в 1923 г. [О партийной..., 1954, с.275].

Противопоставление и противостояние было не только стилистическим, но и организационным. Весной 1923 г. в связи с возобновлением работы кинофабрик он с нескрываемым сожалением наблюдает, как кинопроизводственники в поисках инсценировок перелистывают тексты популярных литературных произведений, театральных драм, в зародыше отравляя организм кинематографа, воспроизводя буржуазные привычки в той же степени, в какой нэпманы воспроизводят дореволюционную буржуазию [Дзига Вертов..., 1966, с.52]. Созвучие творчества Вертова коммунистической идеологии, практике советской власти того времени очевидна. «Киноправду» в прокате удалось противопоставить «Индийской гробнице». Удалось запустить «Киноглаз» и сообщество «киноков», которых Вертов противопоставлял «стаду старьевщиков» на кинофабриках, занимавшихся затуманиванием сознания масс. Планы Вертова грандиозны. Они включали полный разгром фальши и театральности буржуазного кино на основе развертывания кинофабрики фактов как объединения всех видов «киноглазовской» работы: текущей хроники, научных 
картин, тематических «Киноправд». Перспективу массовой съемки, сортировки, распространения фактов он понимал как «подлинную кинофикацию рабоче-крестьянского СССР», противостояние «киноколдовству» и «киномистификации», оплоты которых он видел в Ленинградской фабрике эксцентрического актера (ФЭКС Г. Козинцева и Л. Трауберга), «фабрике аттракционов» С. Эйзенштейна, зарубежных и отечественных кинофабриках поцелуев, голубей и ужасов [Вертов, 2008, с.116].

Но тень на отношения власти и Вертова уже легла. И вырастала она из позиции самого Вертова, которому ситуация в кинохронике виделась особенно болезненной в силу прикованности, с одной стороны, к политическим событиям, а с другой к предпочтениям рынка. И съемка политическая, и съемка под давлением экономических условий, по мнению Вертова, не считаются с кинематографичностью сюжетов, мешают раскрытию поэзии материала.

Со временем творческий метод Вертова из экспериментальных поисков вырос и вызрел до целостной «кинописи» [Вертов, 2004, с.285], понятной без перевода на язык слов. После виртуозного видеозвукового монтажа киносимфонии «Трех песен о Ленине» Вертов писал, что предпочел бы делать фильмы без словесных сценариев, сразу изображениями и звуками - подобно художнику, который пишет сразу карандашом или красками, а композитор пишет музыку сразу нотами или звуками [Вертов, 2004, с.262-263]. И в становлении этой авторской кинописи Вертов, отрицавший «психологизм», сам все больше проявлял интерес к передаче тонкостей личностных переживаний средствами документального кино. Это выражалось, прежде всего, во все большем внимании Вертова не столько к движениям человеческих масс, сколько к переживаниям и эмоциям конкретных людей, их характерам, их индивидуальной неповторимости.

В 1935 г. он вспоминал о многих сотнях, а то и тысячах страниц, исписанных в процессе съемок и монтажа «только для того, чтобы уничтожить написанное в момент, когда приходит такое ясное и простое, как улыбка бетонщицы Белик, решение» [Вертов, 2008, с.287]. А в дневнике 1944 г. он писал о схематичности и приблизительности любого сценария, ориентированного на документально фиксируемое поведение людей, даже если знаешь, что произойдет с ними в ближайшее время. Оно всегда будет другое. Поэтому в документальном кино, по его мнению, нет и не может быть предварительного «точного» согласования, требуемого руководством.

В советском же искусстве, включая кино (а документалистика находилась на стыке искусства и пропаганды), утверждалась образность не столько человеческой индивидуальности, сколько типажей. Кроме того, в поэтическом документальном кинематографе Вертова определяющим началом была личность автора, его позиция и «власть» над материалом. А это уже стало основанием для прямой «ревности», доходящей до нетерпимого отношения кинематографических властей к художнику.

Документальное кино Вертова - не документальный протокол, не просто «революционный маяк на фоне театральных шаблонов мирового кинопроизводства». Это «пафос фактов как энтузиазм фактов» [Дзига Вертов..., 1966, с.123]. И такая установка вызывала критику и неприятие даже у бывших соратников по ЛЕФу. Так, В.Б. Шкловский в 1927 г. расценивал творчество Вертова как художественно прогрессивное, но нарушающее «законы хроники», которая должна представлять факт как таковой, точно обозначенный - датированный и подписанный, тогда как у Верто- 
ва исчезает фактичность кадра, а вещь теряет вещественность, превращаясь в подобие произведений символистов [Шкловский, 1927]. Против вертовской «субъективности» и «экспрессионистичности» выступал даже Л. Кулешов - автор знаменитого «эффекта Кулешова», когда из одного и того же отснятого киноматериала с помощью монтажа можно получать совершенно различные по смыслу композиции. Он упрекал Вертова именно в субъективно художественном монтаже, когда «монтаж не обслуживает материал с целью возможно лучшей его подачи, а был индивидуально творческим моментом монтажера» [Кулешов, 1927, с.32]. По мнению Кулешова, монтаж в документальном кино, в отличие от игрового, определяется не автором, а материалом, выявлением тематической сущности материала, он не должен «демонстрировать субъективное впечатление художника от событий, как бы правильны ни были его, художника, убеждения» [Кулешов, 1927, с.33].

К ранним обвинениям рапповцев в формализме добавились упреки лефовцев в уводящем от жизни символизме. Такие упреки подкреплялись припоминанием киночества 1920-х как «групповщины». Все вместе это складывалось в общий фон этакого «буллинга», стремление вытеснить Вертова из активного профессионального творчества.

Сам же Вертов переосмыслял свое не столь давнее прошлое в совершенно ином ключе. Делясь опытом в 1934 и 1958 гг., он отмечал, что одной из основных задач «киноглаза» было «научиться читать мысли людей, выявлять их чувства, ловить мгновения предельной искренности» [Дзига Вертов..., 1966, с.136; с.154-160], что сцены «не игры» живых людей в «Трех песнях о Ленине» «перекликаются в нашей памяти с женой задохнувшегося сторожа из “Жизни врасплох", с детьми в “Человеке с киноаппаратом", с молящимися в “Энтузиазме” и т.д.» [Вертов, 2008, с.276]. Справедливости ради стоит отметить, что переклички, эти слегка натянутые, являются скорее поздней рефлексирующей рационализацией пройденного пути. Девушка с наушниками, слушающая советское радио в контрапункте с церковным звоном, довольно долго присутствует в «Энтузиазме» - почти всю первую четверть фильма - и явно могла бы стать сквозной его темой. Но эта девушка напрочь лишена каких-то внятных эмоций, а на крупных и сверхкрупных планах фигурируют только части ее лица, прежде всего - ухо с наушником. Тем не менее этот образ не только лишен конкретного психологизма, он не рождает даже ассоциаций ни с «радиоухом», ни - тем более - с «киноглазом». И неспроста автор забывает о ней ради пафосных маршей и ритмов массовых проходов и действий машиноподобных обезличенных людей, чередующихся с действиями шахтеров.

Но в середине 1930-х Вертов задумывает ряд киноочерков о живых людях, галерею кинопортретов современников. Собственно, уже в «Трех песнях о Ленине» и дальше по нарастающей - в фильмах «Колыбельная» (1937), «Три героини» (1938), фильмах военного времени («В районе высоты», «Кровь за кровь, смерть за смерть», «Тебе, фронт!», «В горах Алатау», «Клятва молодых») - на первом плане для Вертова были уже конкретные люди.

В этом Вертов - как чуткий художник - полностью вписывался в общий «персонологический» сдвиг гуманитарной парадигмы не только в искусстве, но и в философии, в исторической науке. Экзистенциализм и неомарксизм А. Грамши, Д. Лукача, М. Лифшица, франкфуртская школа (Т. Адорно, М. Хоркхаймер) + аналити- 
ческая психология (фрейдизм и неофрейдизм), историческая школа «Анналов» Э. Блоха и Л. Февра, в литературе - Э.-М. Ремарк, Р. Олдингтон, Р. Музиль, Г. Гессе, Т. и Г. Манны - все они по-разному, но проявляли все больший интерес не столько к социальной жизни в движениях масс и классов, сколько к жизни отдельных людей, их обыденному опыту и переживаниям. После войны эта тенденция ярко выразилась в итальянском неореализме, в отечественной «лейтенантской прозе» об «окопной правде» войны.

Такие поиски резко расходились с представлениями партийного руководства советского кинематографа. В 1920-х, особенно в годы «Великого перелома», сворачивания НЭПа, курса на коллективизацию и индустриализацию, вертовский пафос противостояния коммерции, мещанским вкусам, яркая пропаганда энтузиазма слома старых устоев и работы по строительству нового мира соответствовали видению партийным руководством роли, места «важнейшего из искусств». Но в 1930-е гг. ситуация была уже иной. Требовалось не срывание шор, взрывание стереотипов, а мифология исторических героев: от Ивана Грозного до В.И. Чапаева, Н.И. Щорса; требовался пафос прославления мудрого руководства партии, силы Красной армии и радости уже сложившегося быта «простых советских людей» (ключевое слово «советских»). Роман Вертова с советской властью оказался ярким, но недолгим и невзаимным. Не случайно он видел много общего в своей ситуации и положении, в каком оказался его друг В. Маяковский [Дзига Вертов, 1966, с.182-186; с.262-263].

Вертовские заявки на темы о «живом человеке» отклонялись как нарушающие стандартное представление (сейчас бы сказали - формат) документальности. Его «кинопись» или не понималась (в лучшем случае), или отторгалась как ненужная, а то и чуждая своим «формализмом». Да и ему самому уже было тесно в сжимавшихся тисках между идейно-политическим заказом и организационно-экономическими требованиями обюрокраченного кинопроизводства.

Нельзя исключать и еще один немаловажный повод «ревности» власти к Вертову - его акцентированное внимание к фигуре Ленина, возвеличивание его образа вождя мирового пролетариата, открывшего новые горизонты переустройства мира, через благодарное воспевание отношения к нему простых тружеников. Д. Вертов и Е. Свилова отдали много сил и времени поиску и реконструкции кинокадров, запечатлевших Ленина, фонограмм его голоса. Не только в его отснятых фильмах, но в заявках практически не присутствует тот, кого называли «Лениным сегодня». А этот человек уделял повышенное внимание не только игровому кинематографу. Думается, не случайно «Три песни о Ленине» были признаны лишь через год после выхода, «Колыбельная» - принудительно искажена при монтаже и практически замалчивалась и разрушалась при хранении. Вымотавшие Вертова вынужденные бесконечные переделки практически разрушили фильм «Серго Орджоникидзе» (1937). А в дальнейшем вертовские заявки, поддержанные руководством студий, даже запущенные в пробные съемки (как это было со «Сказкой о Великане»), тормозились на уровне партийного руководства, ЦК ВЛКСМ без особого разъяснения причин. Неожиданное предложение снять фильм «Ленин» в 1944 г. практически тут же без объяснений было отозвано.

Органично созвучный в 1920-е гг, Вертов плохо вписывался в советскую действительность последующего двадцатилетия. Он немного не дожил до 1960-х, когда 
и в отечественном киноискусстве проснулся и стал мейнстримом интерес к отдельному человеку и его переживаниям.

А при жизни... Даже фильм о герое Великой Отечественной войны летчике И. Покрышкине, снять который мечтал Вертов, поручили другому документалисту. Вертовский дневник конца 1940-х гг. фиксирует, насколько болезненно он переживал происходящее с ним, не видя выхода из «круга неприязни и нелюбви», наблюдая, как его идеи и проекты успешно реализуются другими, в том числе за рубежом. Отлучение от реальной работы, странные предложения работы на «Детфильме», «Мостехфильме», заканчивающиеся ничем, как только Вертов брался за любые проекты. В дневниках он описывал, что чувствует будто он «замурован», сравнивал свое положение с попытками использовать скрипку в качестве теннисной ракетки, а флейту - для выбивания пыли из ковров [Дзига Вертов, 1966, с.264].

Он пытался объяснить ситуацию, пеняя на сложившуюся практику производства документальных фильмов, воцарение штампов, изгнание творческой изобретательности, общее снижение качества кинопродукции. Но, так или иначе, ни один из его поздних замыслов осуществлен не был: ни «Девушка двух миров» (как «Девушкакомпозитор», 1936 и «Девушка играет на рояле», 1939), ни фильм-песня «Письмо трактористки» (1941), ни «Галерея кинопортретов» и даже отдельный кинопортрет «Маленькая Аня» (1944) о реальной героической девушке-партизанке и ее переходе к мирной жизни. Некоторые заявки отклонялись без рассмотрения, оставались без ответа. В оставшиеся 10 лет (1944-1954) он уже даже не снимал, а монтировал «фактичность» киножурнала «Новости дня», подрабатывая иногда на разгрузке барж с дровами.

Другими словами, Вертов в полной мере испил чашу ответственности за особенности восприятия его творчества современным ему обществом, что, как говорилось в начале этой статьи, позволяет рассматривать его судьбу как судьбу античного парресора, наиболее известным из которых был Сократ, судьба которого и его отношение к ней хорошо известны.

Термин «парресия» ( $\pi \alpha \rho \rho \eta \sigma i ́ \alpha$, parrhēsía), происходящий от греческих корней $\pi \tilde{\alpha} v$ (все) и $\dot{\tilde{\eta} \sigma \iota \varsigma ~(р е ч ь, ~ в ы с к а з ы в а н и е), ~ и м е е т ~ ш и р о к и и ̆ ~ с п е к т р ~ з н а ч е н и и ̆: ~ о т ~ « г о в о р е н и е ~}$ всем и обо всем» до «свободы слова». Однако в процессе античных и христианских дискурсивных практик за ним закрепилось применение к ситуации высказывания искреннего, откровенного и ответственного. Упоминавшийся анализ этого концепта, проведенный М. Фуко, показал, что герменевтика парресии позволяет вывести качества коммуникативного контента за рамки критериев истинности к прагматическим и этическим контекстам. В этом случае акцент переносится с оценки истинности на отношение к истине, на феномен «взятия слова» и ответственности за высказанное, включая то, что способно вызывать негативную реакцию аудитории - как отдельных адресатов, так и целых сообществ, включая гнев и возможные санкции к парресору.

Такой подход представляется особенно важным и актуальным применительно к современным практикам сетевых коммуникаций, в которых владельцы аккаунтов получают исключительные возможности «брать слово» - формулировать и представлять свою позицию по самым различным вопросам: от фактов личной жизни до дискуссий на научные, политические и религиозные темы. 
Фуко, заставший начало этого тренда, отрицал возможность парресии в современном мире, в котором технологии коммуникации позволяют оторваться от истинности, делая представляемую информацию все более безответственной. Вербальные и невербальные фейки, переполнившие медиа, казалось бы, это подтверждают. Тема постправды, индустриального производства фейковой информации, возможности противостоять ей - сверхактуальная. Ей посвящаются конференции, круглые столы, масштабные аналитические исследования. Между тем, как представляется, речь идет о глубокой изначальной особенности коммуникации, которая благодаря современным технологиям, в первую очередь - Интернету и социальным сетям, вышла на первый план, что позволяет не только по-новому, но и глубже понять природу коммуникативных процессов, транслируемого в них контента, реакций на него. Вертов не знал социальных сетей и Youtube, но его опыт «Киноправды», «Киноглаза» и киночества удивительно вписывается в современные практики.

В терминах социальной семиотики и ее расширения в плане «глубокой семиотики» (deep semiotics) [Тульчинский, 2019] речь идет о переносе акцента с социальных значений (предметных и ценностно-нормативных) на личностные смыслы, т.е. оценочно-эмоциональные компоненты представляемого и транслируемого смыслового содержания опыта. Если ранее социальная коммуникация преимущественно была связана с выделением и трансляцией социальных значений - относительно устойчивых образцов, стилей, транслирующих ценностную культуральную нормативность, то в нынешней ситуации речь идет все больше о презентации и трансляции непосредственно самих уникальных личностных переживаний, иногда даже персонально не агрегируемых. Instagram, отчасти Facebook, Youtube являют поток репрезентаций личностных смыслов «от первого лица». Они направлены не столько на порождение некоего опыта сопереживания, сколько на презентацию самих переживаний и их распознавание. Именно это и практиковал Вертов.

По содержанию такой опыт представляет собой нарративную дискурсивную практику, которая является основой формирования и презентации самосознания выстраивания наррации «от первого лица», в которой личность предстает актором своей биографии (autobiographically myself [Damasio, 2010]), а связность такой наррации представляет память. Реализоваться такая наррация может только в коммуникативных практиках публичной и внутренней речи, описывающей социальный опыт и отношение к нему в процессе социализации и индивидуализации.

При этом важно отдавать отчет в том, что осмысленная информация как контент социальной коммуникации есть изначально именно порождение наррации «от первого лица». Любой конечной системе (а таковой является и человеческая личность) недоступно бесконечное разнообразие мира. Поэтому она вынуждена постигать это разнообразие всегда с какой-то позиции, в каком-то ракурсе, в каком-то отношении - в каком-то смысле. Осмысленная информация есть порождение конечной системы, и в каком-то смысле она неизбывно «фейковая», если не изначально, то с возможной позиции оценивания кем-то.

В современной ситуации фактически речь идет о широчайших возможностях позиционирования самосознания (идентичности) «от первого лица», погружения его в контекст публичной социальной коммуникации, где оно предстает уже в формате «от третьего лица» (как идентификация), получая обратную связь в виде позитивных 
и негативных оценок - вплоть до институционального социального контроля. Кроме того, возникает вопрос о спецификации роли социального статуса «взятого слова» на особенности и масштаб формирования смысловой картины мира [Гройс, 2016].

Не случайно современные дискуссии выявляют главный этико-правовой, если не антропологический парадокс цивилизационных условий современной социальной жизни.

Возможности и право личности на самовыражение своего мнения, своей позиции порождает обилие спорных, неоднозначных оценок, вызывающих сомнение в добросовестности информации, стимулирует индивидуальные и институциональные способы фильтрации такой информации, без которых современная парресия возвращается к одному из своих первоначальных античных значений безответственного «говорения и показа чего угодно», следствием чего становится все более жесткий контроль за сетевым контентом.

В новейшей философии также диагностируется формирование нового мировоззрения, миропонимания и мироощущения, сменяющего постмодернистский деконструктивизм и иронию. Речь идет о так называемом метамодернизме с его переходом от тотального отстранения смыслов к их новому монтажу, новой целостности и цельности, а главное - искренности [Metamodernizm, 2017; Павлов, 2018]. Речь идет не о наивности и романтизме, а о том, что современный художник, политик, ученый, любой человек, претендующий на высказывание своей позиции, своей точки зрения, выступает в этих новых условиях фактически как античный парресор, ответственно, с открытым сердцем говорящий (возможно, горькую) правду «городу и миру». И если он «берет слово», то сам этот факт, как и публично произнесенное (написанное) слово, выступает как поступок вменяемого актора, понимающего меру и глубину своего «не алиби в бытии» [Бахтин, 1986]. А в условиях тотальной медиализации в цифровом формате эта ответственность обретает все новые и новые измерения, являющиеся серьезнейшими вызовами традиционным представлениям о морали и праве.

До самого последнего времени доминантной выступала характеристика парресии как анахронизма, «бесстрашной речи» (fearless speech), уместной в Античности, но не в современности, для которой характерна свобода слова (freedom of speech). Эти два концепта даже иногда противопоставляются друг другу на том основании, что для современного социума характерны институты либеральной демократии с ее фундаментальными правовыми гарантиями свободы слова и совести как гарантиями человеческого бытия как такового. Дело даже доходит до альтернативы выбора между популистским авторитарным режимом с парресией и демократией со свободой слова [Karadut, 2018], а претензии на парресию рассматриваются как угроза: когда права всех становятся привилегией немногих, ни свобода, ни равенство не могут длиться долго [Bejan, 2017].

В результате в современном обществе, как отмечалось участниками Круглого стола «Права человека и дисбаланс взаимной ответственности», проведенного Российской ассоциацией политической науки и Высшей школой экономики (СанктПетербург, 17-19 октября 2019), в связи с развитием цифровых технологий коммуникации, оперирования большими данными, формированием электронного правительства и т.п. возникает противоречие между правом личности на свободу слова 
(чреватым разрастанием фейковых новостей, постправды, практик травли и буллинга) и правом личности на тайну личной жизни, защиту репутации [Материалы дискуссий..., 2019]. Поэтому все более пристального специального внимания заслуживает тема баланса прав и ответственности (моральной и правовой) в практике как пропаганды прав человека, так и организации сетевой коммуникации. В этой связи, как представляется, созревают условия для пересмотра оценки Фуко перспектив феномена и концепта парресии применительно к современным дискурсивным практикам. Трансформация развернувшегося в 2020 г. дискурса коронавирусной пандемии может служить очень поучительным кейсом [Тульчинский, 2020].

В условиях тотальной медиализации в цифровом формате эта ответственность обретает все новые и новые измерения, являющиеся серьезнейшими вызовами традиционным представлениям о морали и праве. В современном цифровизованном информационном обществе позитивная парресия - не привилегия немногих, а нравственный тестирующий долг «берущих слово».

Осмысление возвращения парресии вполне соотносится с философией поступка как вменяемого (рационального и ответственного) действия, включая публичную речь и самопрезентацию. В Античности (первое упоминание парресии встречается в трагедии Еврипида «Ион») парресия была связана с «изегорией» (равенством речи) и «изономией» (равным участием свободных граждан полиса в осуществлении власти). Благодаря этому парресор «брал слово» во всем контексте (политическом, экономическом, моральном, религиозном) жизни социума прямой демократии агоры. И для некоторых парресоров, как известно из случая с Сократом, это заканчивалось печально.

Аналогично фигурой был Вертов с его отрицанием игры и масок, стремлением выстроить кинодокумент, отражающий реальную жизнь, в котором камера - не просто фиксатор жизни, а инструмент понимания и осмысления этой жизни в руках человека. И результатом такого осмысления являются не просто личные впечатления, а убежденность в правоте преодоления стереотипов, чувства и страсть переживания этой убежденности, не просто оценочное отношение к реальности, а ответственное выражение своей позиции, донесение ее от человека к человеку с помощью кинокамеры. Жизнь у него отнята не была, но возможности реализовать творческие планы он оказался лишен.

Наше время вроде бы предстает торжеством безответственности и отрицательной парресии «всеговорения о чем угодно». Однако в этой связи можно признать, что негативная парресия (как и связанные с нею фейки и постправда) суть следствие институционального склероза [Olson, 1982] гипертрофированных прав на свободу безответственного слова на ранних стадиях Web-пространства. Поэтому рано или поздно, но должен был вызреть запрос на коррекцию негативной парресии, нарушающей человеческое достоинство, угрожающей репутации, благополучию, а то и жизни других людей. Он вызревает вместе с указанной выше динамикой становления «метамодернистской культуральной парадигмы». Цифровизация публичной коммуникации только усиливает и закрепляет данный тренд.

При этом стрессовые ситуации, особенно столь глобальные, как коронавирусная пандемия, усиливают вызревание тренда на позитивную парресию, не только корректирующую негативную парресию, но и репрезентирующую конструктивные по- 
зитивные образцы, что делает эти нарративы нравственными перформативами. Реализация такой парресии становится важнейшим фактором противостояния опасным популистским решениям «харизматичных» лидеров, в том числе в плане противостояния экзистенциальным опасностям вроде пандемии, когда под вопрос ставятся не рыночные котировки, а жизни конкретных людей и даже групп людей.

В такой ситуации возникают «изегория» и «изономия» перед лицом угрозы, которую негативная парресия только усиливает, приводя к неадекватным решениям и действиям, а остро востребованным становится «позитивный парресор». Он может подвергнуться давлению, гонениям, преследованиям, доносимое им слово не сразу становится признанным фактом. Но это не означает, что взятое им слово не является социально значимым.

В современном цифровизованном информационном обществе позитивная парресия - не привилегия немногих, а нравственный тестирующий долг «берущих слово». Можно сказать, что античная парресия возвращается в новом формате. Дзига Вертов опередил свое время не только стилистикой и содержанием своего творчества, но своею личной судьбой, заставляя вновь и вновь обращаться к их осмыслению со все возрастающим интересом и уважением.

\section{Литература}

Бахтин М.М. К философии поступка. Философия и социология техники. Ежегодник. 1984-1985. М.: Наука, 1986. - С.80-160.

Вертов Д. Из наследия. Т.1. Драматургические опыты / Отв. ред. А. Дерябин. М.: Эйзенштейн-центр, 2004. $-536 \mathrm{c}$.

Вертов Д. Из наследия. Т. 2. Статьи и выступления / Отв. ред. Д.В. Кружкова, С.М. Ишевская. М.: Эйзенштейн-центр, 2008. - 648 с.

Гройс Б. В потоке. М.: Ad Marginem, 2016. - 208 c.

Делез Ж. Кино. Кино-1: Образ-движение. Кино-2: Образ-время. М.: Ad Marginem, 2004. - 624 с.

Дзига Вертов. Статьи, дневники, замыслы. М.: Искусство, 1966. - 320 с.

Материалы дискуссий российских правозащитников, экспертов и ученых в 2019 году / Сост. С. Кривенко. М.: Изд. коалиции правозащитников, 2019. - С.107-120.

Кулешов Л. Экран сегодня // Новый ЛЕФ. 1927, № 4. - С.31-34.

О партийной и советской печати. Сборник документов. М.: Правда, 1954. -690 с.

Павлов А. Образы современности в XXI веке: метамодернизм // Логос. 2018, Т. 28, № 6. - С.1-19.

Темлякова А.С. Герой фильма Дзиги Вертова «Человек с киноаппаратом» (1929): человек ли это? // Лабиринт. Журнал социально-гуманитарных исследований. 2016, № 6. - С.108-113.

Тульчинский Г.Л. Публичный дискурс в условиях коронавирусной пандемии: возвращение парресии // Общество. Коммуникация. Образование. 2020. Т. 11, №2. - С.14-29.

Тульчинский Г.Л. Расширение возможностей семиотического анализа: источники и содержание концепции «глубокой семиотики» // Вопросы философии. 2019, №11. - С.115-125.

Фуко М. Речь и истина. Лекции о парресии (1982-1983). М.: ИД «Дело» РАНХиГС, 2010. - 384 с.

Шкловский В.Б. Их настоящее: [О советских кинорежиссерах]. М.; Л.: Кинопечать, 1927. - 112 с.

Bejan T.M. The Two Clashing Meanings of 'Free Speech' [https://www.theatlantic.com/politics/ archive/2017/12/two-concepts-of-freedom-of-speech/546791/].

Damasio A. Self comes to mind: Constructing the conscious brain. N.Y.: Pantheon, 2010. $-367 \mathrm{p}$.

Karadut I.C. Truth-telling in the era of post-truth: Two cases of parrhesia for democracy // The Internet, Policy \& Politics Conference 2018. Oxford Internet Institute (OII) / University of Oxford [http://blogs.oii.ox.ac. uk/policy/wp-content/uploads/sites/77/2018/08/IPP2018-Karadut.pdf].

Metamodernism: Historicity, affect, and depth after postmodernism (Radical cultural studies). Lanham (Maryland): Rowman \& Littlefield, 2017. - 260 p.

Olson M. The rise and decline of nations: Economic growth, stagflation, and social rigidities. New Haven (CT): Yale University Press, 1982. - 273 p. 


\section{References}

Bakhtin M.M. K filosofii postupka. Filosofiya i sociologiya tekhniki. Ezhegodnik. 1984-1985 [Toward a philosophy of the act. Philosophy and sociology of technique. Yearbook. 1984-1985]. M.: Nauka, 1986. - Pp.80-160.

Vertov D. Iz naslediya. T.1. Dramaturgicheskie opyty [From the heritage. Vol.1. Drama experiments] / Editorin-chief A. Deryabin. M., Ejzenshtejn-centr, 2004. - 536 p.

Vertov D. Iz naslediya. T. 2. Stat'i i vystupleniya [From the heritage. Vol. 2. Articles and speeches] / Editor-inchief D.V. Kruzhkova, S.M. Ishevskaya. M.: Ejzenshtejn-centr, 2008. - 648 p.

Groys B. V potoke [In the flow]. M.: Ad Marginem, 2016. - 208 p.

Deleuze G. Kino. Kino-1: Obraz-dvizhenie. Kino-2: Obraz-vremya. [Cinema-1: The movement image. Cinema-2: The time image.] M.: Ad Marginem, 2004. - 624 p.

Dziga Vertov. Stat'i, dnevniki, zamysly [Articles, diaries, projects]. M.: Iskusstvo, 1966. - 320 p.

Krivenko S. (comp.) Materialy diskussij rossijskih pravozashchitnikov, ekspertov i uchenyh v 2019 godu [Discussion materials of Russian human rights defenders, experts and scientists in 2019]. M.: Publishing house of human rights defenders coalition , 2019. - Pp.107-120.

Kuleshov L. Ekran segodnya [Screen today] // Novyj LEF [New LEF]. 1927, No. 4. - Pp. 31-34.

$O$ partijnoj $i$ sovetskoj pechati. Sbornik dokumentov [About the party and Soviet press. Collection of documents]. M.: Pravda, 1954. - 690 p.

Pavlov A. Obrazy sovremennosti v XXI veke: metamodernizm [Images of the present in the 21st century: metamodernism] // Logos [Logos]. 2018, Vol. 28, No. 6. - Pp.1-19.

Temlyakova A.S. Geroj fil'ma Dzigi Vertova «CHelovek s kinoapparatom» (1929): chelovek li eto? [The character Dziga Vertov's movie «Man with a movie camera» (1929): is this a man?] // Labirint. Zhurnal social'no-gumanitarnyh issledovanij [Labyrinth. The Journal of Social and Humanitarian Studies]. 2016, No. 6. - Pp. 108-113.

Tulchinsky G.L. Publichnyj diskurs v usloviyah koronavirusnoj pandemii: vozvrashchenie parresii [Public discourse in the context of the coronavirus pandemic: the parrhesia return]// Obshchestvo. Kommunikaciya. Obrazovanie [Society. Communication. Education]. 2020. Vol. 11, No. 2. - Pp. 14-29.

Tulchinsky G.L. Rasshirenie vozmozhnostej semioticheskogo analiza: istochniki i soderzhanie koncepcii "glubokoj semiotiki» [Extensions of the semiotic analysis capabilities: the sources and content of the «deep semiotics» concept] // Voprosy filosofii [Problems of philosophy]. 2019, No. 11. - Pp. 115-125.

Foucault M. Rech'i istina. Lekcii o parresii (1982-1983) [Discourse and truth. Lectures on parrhesia (19821983)]. M.: Publishing house «Delo» Ranepa, 2010. - Pp. 384.

Shklovsky V.B. Ih nastoyashchee: [O sovetskih kinorezhisserah] [Their present: [About Soviet filmmakers]]. M.; L.: Kinopechat', 1927. - 112 p. 